\title{
EFEKTIFITAS PEMBERIAN ZINC DALAM PENINGKATAN TINGGI BADAN (TB) ANAK STUNTING DI KABUPATEN PATI
}

\author{
Uswatun Kasanah $^{1)}$, Siti Muawanah ${ }^{2)}$ \\ ${ }^{1}$ Prodi Sarjana Kebidanan, Stikes Bakti Utama Pati \\ ${ }^{2}$ Prodi Pendidikan Profesi Bidan, Stikes Bakti Utama Pati \\ Email: uswatun@stikesbup.ac.id
}

\begin{abstract}
ABSTRAK
Berdasarkan Riset Kesehatan Dasar (Riskesdas) 2010 diketahui prevalensi stunting pada balita di Indonesia mencapai $35,7 \%$. Stunting pada balita dapat merugikan perkembangan fisik, dan berpengaruh terhadap tingkat kecerdasan yang rendah. Anak yang mengalami stunting memiliki risiko 9 kali lebih besar untuk memiliki nilai IQ di bawah rata- rata dibandingkan anak yang berstatus gizi normal. Salah satu faktor yang berpengaruh secara langsung pada balita stunting adalah rendahnya asupan zat gizi terutama energi, protein, iron, zinc, dan kalsium. Berdasarkan Riskesdas (2018), Kabupaten Pati menduduki peringkat kedua se-Jawa Tengah, dimana data dari Dinas Kesehatan Kabupaten Pati per-April 2019 diperoleh bahwa wilayah Puskesmas Jakenan menduduki peringkat pertama, disusul Puskesmas Gabus II. Penelitian bertujuan mengetahui efektifitas pemberian zinc ( $20 \mathrm{mg}$, 2x seminggu selama 3 bulan) pada anak stunting dengan membandingkan terhadap kelompok kontrol, menggunakan desain penelitian eksperimen randomized pretest posttest control group design di Kab. Pati tahun 2020. Jumlah sampel 20 anak stunting. Penelitian menunjukkan bahwa ada perbedaan yang signifikan pada tinggi badan (TB) anak yang mendapat zinc dibandingkan dengan kelompok anak kontrol dengan nilai $\mathrm{p}$ value 0.001. Adapun rata-rata kenaikan TB anak stunting pada kelompok intervensi adalah $3,35 \mathrm{~cm}$ sedangkan pada kelompok kontrol hanya $1 \mathrm{~cm}$. Untuk BB anak kelompok intervensi rata-rata naik $0,885 \mathrm{~kg}$ sedangkan pada kelompok kontrol hanya $0,17 \mathrm{~kg}$. Penelitian ini merekomendasikan pemberian zinc kepada balita stunting terutama usia kurang dari 2 tahun secara rutin $2 x$ seminggu sebanyak $20 \mathrm{mg}$ $(10 \mathrm{ml})$ dengan tetap memantau berkala serta mengonsumsi makanan sebagai sumber nutrisi bagi balita stunting.
\end{abstract}

Kata Kunci: zinc, stunting, tinggi badan (TB)

\begin{abstract}
Based on Riskesdas 2010, the prevalence of stunting in children under five in Indonesia reaches $35.7 \%$. Stunting in children under five can be detrimental to physical development and affect low intelligence levels. Stunting is nine times more likely to have IQ scores below the average than children with normal nutritional status. One of the factors that directly influence stunting under five is the low intake of nutrients, especially energy, protein, iron, zinc, and calcium. Pati Regency is in second place in Central Java, where data from the Pati District Health Office as of April 2019 shows that the Jakenan Health Center area is ranked first. This study aimed to see the effectiveness of giving zinc ( $20 \mathrm{mg}$, twice a week for three months) to stunting children by comparing it to a control group, using a randomized pretest-posttest control group design. The total samples are 20 children. The study showed that there was a significant difference in the height of children who received zinc compared to the control group with a value of 0.001 . The average increase height in the intervention group was $3.35 \mathrm{~cm}$, while in the control group it was only $1 \mathrm{~cm}$. The weight of children in the intervention group an average increase of $0.885 \mathrm{~kg}$ while in the control group was only $0.17 \mathrm{~kg}$. This study provides information to stunting toddlers, especially those aged less than two years, twice a week as much as $20 \mathrm{mg}$ regularly and consuming food as a source of nutrition for stunting toddlers.
\end{abstract}

.Keywords: zinc, stunting, height 


\section{PENDAHULUAN}

Stunting adalah postur tubuh pendek yang timbul karena malnutrisi kronis. ${ }^{1}$ Kategori stunting didasarkan pada indeks Panjang Badan menurut Umur (PB/U) atau Tinggi Badan menurut Umur (TB/U) dengan ambang batas (z-score) antara -3 SD sampai dengan < 2 SD. ${ }^{2}$ Berdasarkan Riset Kesehatan Dasar (Riskesdas) 2010 diketahui prevalensi stunting pada balita di Indonesia mencapai $35,7 \% .^{3}$ Stunting pada balita dapat merugikan perkembangan fisik, dan berpengaruh terhadap tingkat kecerdasan yang rendah. ${ }^{1}$ Anak yang mengalami stunting memiliki risiko 9 kali lebih besar untuk memiliki nilai IQ di bawah ratarata dibandingkan anak yang berstatus gizi normal. ${ }^{4}$

Salah satu faktor yang berpengaruh secara langsung pada balita stunting adalah rendahnya asupan zat gizi terutama energi, protein, iron, zinc, dan kalsium. Dalam upaya perbaikan status gizi, termasuk stunting, intervensi dengan satu mikronutrien saja kurang efektif. ${ }^{6}$ Oleh karena itu, untuk melengkapi asupan zat gizi anak, dapat dilakukan dengan menggunakan bahan makanan yang beragam pada MP-ASI karena keragaman makanan yang kurang merupakan prediktor kuat terjadinya stunting. ${ }^{9}$

Pemantauan Status Gizi (PSG) 2017 menunjukkan prevalensi balita stunting di Indonesia masih tinggi, yakni $29,6 \%$ di atas batasan yang ditetapkan WHO (20\%). Penelitian Ricardo dalam Bhutta tahun 2013 menyebutkan balita stunting berkontribusi terhadap 1,5 juta (15\%) kematian anak balita di dunia dan menyebabkan 55 juta anak kehilangan masa hidup sehat setiap tahun. ${ }^{2}$

Status gizi yang baik dapat dicapai bila tubuh memperoleh cukup zat-zat gizi yang adekuat, sehingga memungkinkan terjadinya pertumbuhan fisik, memperlancar proses pertumbuhan yang seimbang untuk pengangkutan oksigen dan nutrisi agar sel-sel dapat tumbuh untuk menjalankan fungsinya dengan normal. Zat gizi adekuat memungkinkan pertumbuhan seimbang karena zat gizi akan mengangkut oksigen dan nutrisi ke seluruh tubuh. Namun ada kalanya, zat gizi yang diasup anak tidak mampu memberikan nutrisi secara adekuat karena faktor penyerapan zat gizi tersebut. Karena tidak optimal penyerapannya maka pertumbuhan anak belum berlangsung optimal. Zinc suplemen akan mengoptimalkan penyerapan makanan dan memperbaiki proses tumbuh kembang anak. Anak stunting dapat dipengaruhi dari status gizi ibu sejak kehamilan dimana salah satu indikatornya adalah berat badan bayi saat lahir. Berkaitan dengan status gizi buruk balita di Kabupaten Pati pada tahun 2015 menurut indeks BB/TB terdapat 71 orang $(0,08 \%)$, kasus ini turun dibandingkan 2014 sebanyak 85 orang $(0,10 \%)$.

Upaya perbaikan stunting sebaiknya difokuskan pada anak usia $<2$ tahun karena kisaran usia tersebut merupakan salah satu faktor risiko terjadinya stunting. ${ }^{13}$ Berdasarkan Riskesdas tahun 2018, Kabupaten Pati menduduki peringkat kedua se-Jawa Tengah, dimana data dari Dinas Kesehatan Kabupaten Pati per-April 2019 diperoleh bahwa wilayah Puskesmas Jakenan menduduki peringkat pertama, disusul Puskesmas Gabus II. Berdasarkan uraian di atas, pemberian zinc diduga mempunyai peran penting dalam upaya perbaikan stunting. Oleh karena itu, peneliti tertarik untuk mengetahui efektifitas pemberian zinc pada anak balita stunting di Kabupaten Pati. Tujuan penelitian ini adalah untuk mengetahui perbedaan peningkatan tinggi badan anak balita stunting antara yang mendapat suplemen zinc dan tidak mendapatkannya.

\section{METODE PENELITIAN}

Penelitian ini dilaksanakan di Puskesmas Gabus II serta Puskesmas Jaken Kab. Pati pada bulan Juli s.d. September tahun 2020. Penelitian menggunakan desain penelitian kuasi eksperimen dengan randomized pretest posttest control group design. Populasi dalam penelitian ini adalah seluruh 20 anak balita stunting yang berada di wilayah Puskesmas 
Jaken dan Gabus II Kabupaten Pati. Subjek penelitian adalah semua kelompok perlakuan dan kontrol. Kelompok perlakuan adalah anak balita stunting dengan indeks z-skor TB/U -3 sampai <-2 SD yang diberi suplemen zinc dan kelompok kontrol adalah anak balita stunting dengan indeks z-skor TB/U -3 sampai <-2 SD yang tidak diberi zinc. Kriteria inklusi penelitian ini adalah responden dengan skor $\mathrm{Z}$ $\mathrm{TB} / \mathrm{U}<-2 \mathrm{SB}$, bersedia menjadi responden, konsisten minum suplemen zinc, kooperatif, tidak menderita penyakit kronis dan cacat bawaan, orang tuanya (ibu) bersedia memberikan zinc sesuai jadwal. Kriteria eksklusi adalah anak menderita Penyakit Jantung Bawaan (PJB) atau penyakit lain yang tidak memungkinkan menjadi responden. Jumlah sampel yang digunakan sebanyak 20 subjek pada masing- masing kelompok dan telah ditambah dengan kemungkinan drop out (10\%). Pengambilan subjek dilakukan secara purposive random sampling. Pemberian zinc didefinisikan sebagai pemberian suplemen

\section{HASIL PENELITIAN}

Karakteristik Ibu Responden sirup yang mengandung $20 \mathrm{mg}$ (10 ml) $\mathrm{ZnSO} 4$ $2 \mathrm{x}$ seminggu selama 3 bulan sedangkan kelompok pembanding tidak diberi sirup. Zinc diminum pada pagi hari setelah makan.

Peningkatan TB anak didefinisikan sebagai tinggi badan subyek yang diukur menggunakan mikrotoa dan umur diperoleh dari data tanggal lahir pada buku KMS. Skor Z TB/U dihitung dengan software WHO Anthro 2005. Instrumen penelitian ini menggunakan alat suplemen zinc, serta pengukur TB. Perbedaan pemberian zinc terhadap peningkatan tinggi anak dianalisis menggunakan uji beda. Analisis data dilakukan dengan Mann Whitney dan Wilcoxon test karena data berdistribusi tidak normal. Penelitian ini menggunakan dana hibah penelitian dosen pemula dari DRPM Dirjen Riset dan pengembangan Kemristekdikti tahun anggaran 2020.

Empat puluh ibu responden anak balita stunting yang mendapatkan zinc dan yang tidak mendapat zinc mempunyai karakteristik sebagai berikut:

Tabel 1. Karakteristik Ibu Responden

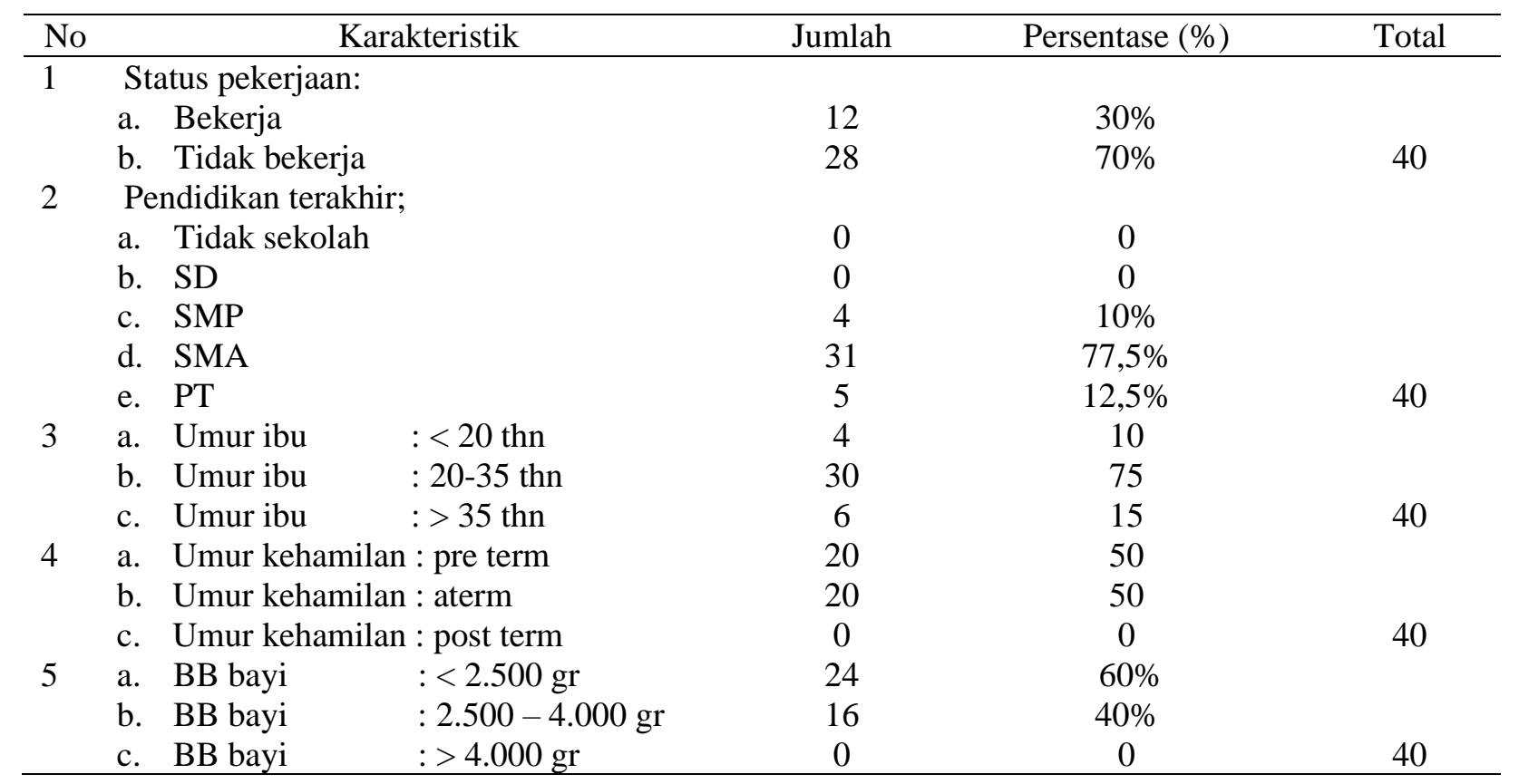

Berdasarkan karakteristik tersebut, diketahui bahwa:

1. sebagian besar ibu tidak bekerja (70\%); 


\section{Community of Publishing in Nursing (COPING), p-ISSN 2303-1298, e-ISSN 2715-1980}

2. sebagian besar responden tamat SMA $(77,5 \%)$

3. sebagian besar umur ibu $20-35$ tahun $(75 \%)$;
4. sebagian kehamilan ibu pre term $(50 \%)$; sebagian aterm $(50 \%)$.

5. sebagian besar berat badan bayi baru lahir kurang dari $2.500 \mathrm{~g}(60 \%)$.

Kelompok Kontrol (tidak mendapat zinc)

Tabel 2. Deskripsi Kelompok Kontrol

\begin{tabular}{|c|c|c|c|c|}
\hline \multirow{15}{*}{ Kenaikan_TB_Kontrol } & & & Statistic & Std. Error \\
\hline & \multicolumn{2}{|l|}{ Mean } & 1,0000 & ,21764 \\
\hline & \multirow{3}{*}{$\begin{array}{l}95 \% \text { Confidence } \\
\text { Interval for Mean }\end{array}$} & Lower &, 5445 & \\
\hline & & Bound & & \\
\hline & & $\begin{array}{l}\text { Upper } \\
\text { Bound }\end{array}$ & 1,4555 & \\
\hline & \multicolumn{2}{|l|}{ 5\% Trimmed Mean } & ,9444 & \\
\hline & \multicolumn{2}{|l|}{ Median } & 1,0000 & \\
\hline & \multicolumn{2}{|l|}{ Variance } & ,947 & \\
\hline & \multicolumn{2}{|l|}{ Std. Deviation } & ,97333 & \\
\hline & \multicolumn{2}{|l|}{ Minimum } &, 00 & \\
\hline & \multicolumn{2}{|l|}{ Maximum } & 3,00 & \\
\hline & \multicolumn{2}{|l|}{ Range } & 3,00 & \\
\hline & \multicolumn{2}{|l|}{ Interquartile Range } & 1,75 & \\
\hline & \multicolumn{2}{|l|}{ Skewness } & ,761 & ,512 \\
\hline & \multicolumn{2}{|l|}{ Kurtosis } &,- 159 & ,992 \\
\hline
\end{tabular}

Berdasarkan tabel 2 tersebut diketahui bahwa rata-rata kenaikan tinggi badan pada kelompok kontrol adalah $1 \mathrm{~cm}$, kenaikan minimal sebesar $0 \mathrm{~cm}$ serta kenaikan maksimal $3 \mathrm{~cm}$.

Kelompok Intervensi (mendapat zinc $20 \mathrm{mg}$ 2x sepekan selama 3 bulan)

Tabel 3. Deskripsi Kelompok Intervensi

\begin{tabular}{|c|c|c|c|c|}
\hline \multirow[t]{15}{*}{ Kenaikan_TB_Intervensi } & \multirow{2}{*}{\multicolumn{2}{|c|}{ Mean }} & Statistic & Std. Error \\
\hline & & & 3,3500 & ,34240 \\
\hline & \multirow{3}{*}{$\begin{array}{l}95 \% \text { Confidence } \\
\text { Interval for Mean }\end{array}$} & Lower & 2,6334 & \\
\hline & & Bound & & \\
\hline & & $\begin{array}{l}\text { Upper } \\
\text { Bound }\end{array}$ & 4,0666 & \\
\hline & 5\% Trimmed Mean & & 3,4444 & \\
\hline & Median & & 3,0000 & \\
\hline & Variance & & 2,345 & \\
\hline & Std. Deviation & & 1,53125 & \\
\hline & Minimum & &, 00 & \\
\hline & Maximum & & 5,00 & \\
\hline & Range & & 5,00 & \\
\hline & Interquartile Range & & 2,00 & \\
\hline & Skewness & &,- 857 &, 512 \\
\hline & Kurtosis & & ,451 & 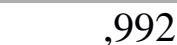 \\
\hline
\end{tabular}


Berdasarkan tabel 3 tersebut diketahui bahwa rata-rata kenaikan tinggi badan pada kelompok intervensi adalah $3,35 \mathrm{~cm}$, kenaikan minimal sebesar $0 \mathrm{~cm}$ serta kenaikan maksimal $5 \mathrm{~cm}$.

\section{Efektifitas Pemberian Zinc Dalam Peningkatan Tinggi Badan (TB) Anak Stunting di Kabupaten Pati}

Penelitian dilakukan pada sekelompok balita stunting yang mendapat zinc $20 \mathrm{mg}$ 2x sepekan selama 3 bulan dan sekelompok balita stunting yang tidak mendapatkan zinc, masing-masing sejumlah 20 balita. Dengan uji Mann-Whitney, diperoleh angka signifikansi 0,000. Karena nilai $\mathrm{p}<0,05$, dapat disimpulkan bahwa ada perbedaan bermakna antara balita stunting yang mendapatkan zinc dengan yang tidak mendapatkan zinc terhadap peningkatan tinggi badan. Hal ini sebagaimana yang tertulis dalam tabel berikut ini

\begin{tabular}{lr}
\multicolumn{2}{c}{$\begin{array}{c}\text { Tabel 4. Hasil Uji Beda } \\
\text { Test Statistics }\end{array}$} \\
& Kenaikan_TB \\
\hline Mann-Whitney U & 47,000 \\
\hline Wilcoxon W & 257,000 \\
\hline Z & $-4,215$ \\
\hline Asymp. Sig. (2-tailed) &, 000 \\
\hline Exact Sig. [2*(1-tailed Sig.)] &, $000^{\mathrm{b}}$ \\
\hline
\end{tabular}

a. Grouping Variable: Tindakan_TB

b. Not corrected for ties.

\section{PEMBAHASAN}

Subyek dalam penelitian ini adalah anak balita stunting usia 2-3 tahun di beberapa desa di wilayah Puskesmas Gabus II dan Puskesmas Jaken Kabupaten Pati dimana subyek dibagi menjadi 2 kelompok; kelompok intervensi yang mendapatkan zinc $20 \mathrm{mg} 2 \mathrm{x}$ sepekan selama 3 bulan serta kelompok kontrol terdiri 20 anak stunting usia 2-3 tahun yang tidak mendapat intervensi zinc.

Hasil penelitian menunjukkan bahwa rerata kenaikan tinggi badan akan kelompok intervensi 3,35 cm sedangkan kenaikan tinggi badan anak kelompok kontrol adalah $1 \mathrm{~cm}$. Pemberian suplementasi zinc pada penelitian ini terbukti mampu meningkatkan tinggi badan secara signifikan dibanding kelompok kontrol hanya naik $1 \mathrm{~cm}$ (rerata).

Lebih lanjut, analisis data dilakukan dengan Mann Whitney dan Wilcoxon test (karena data berdistribusi tidak normal) diperoleh hasil bahwa angka signifikansi 0,000. Karena nilai $p$ $<0,05$, dapat disimpulkan bahwa ada perbedaan bermakna antara balita stunting yang mendapatkan zinc dengan yang tidak mendapatkan zinc terhadap peningkatan tinggi badan. Hal ini berarti pemberian suplementasi zinc terbukti mampu meningkatkan tinggi badan lebih banyak dibandingkan tanpa pemberian zinc.

Hasil penelitian ini sejalan dengan penelitian yang Candra yang menyimpulkan bahwa suplementasi zinc dan zat besi juga terbukti dapat meningkatkan status gizi anak. Pada kelompok 2 (responden minum zinc saja) dan 3 (responden minum zat besi saja) terjadi peningkatan $\mathrm{z}$ skor $\mathrm{BB} / \mathrm{U}$ yang signifikan. Peningkatan berat badan salah satunya disebabkan oleh peningkatan nafsu makan. Namun pada penelitian ini nilai z skor TB/U pada semua kelompok belum meningkat signifikan. Hal ini disebabkan karena jangka waktu pemberian suplementasi yang relatif singkat, hanya 3 bulan. Proses pertumbuhan linier atau pertambahan tinggi badan pada anak di atas 2 tahun berjalan lebih lambat dibandingkan anak di bawah 2 tahun, sehingga dibutuhkan waktu lebih lama untuk meningkatkan tinggi badan secara signifikan. ${ }^{19}$ Sementara itu, Rerksuppaphol 2016 menyimpulkan bahwa pemberian suplementasi zinc selama 6 bulan bisa meningkatkan tinggi badan dan berat badan anak lebih banyak dibanding placebo $(4.9 \pm 1.3$ vs $3.6 \pm 0.9 \mathrm{~cm}, \mathrm{p}$ $<0.001) .{ }^{19}$

Zinc diperlukan untuk melaksanakan fungsi fisiologis, seperti pertumbuhan, imunitas, dan reproduksi. Defisiensi zinc menyebabkan anoreksia, gangguan pertumbuhan, dermatitis, gangguan pengecapan, dan hipogonadisme. Meskipun pada hewan percobaan sudah terbukti bahwa kekurangan zinc menyebabkan anoreksia namun hubungan antara defisiensi zinc dan anoreksia pada manusia masih belum jelas. Diperkirakan zinc meningkatkan nafsu makan 
melalui rangsangan pada saraf vagus yang kemudian mempengaruhi pusat nafsu makan di hipotalamus. ${ }^{19}$ Prevalensi defisiensi zinc pada anak di Indonesia belum diketahui dengan pasti, namun diperkirakan cukup tinggi mengingat pola makan anak di Indonesia yang belum sesuai dengan anjuran pedoman gizi seimbang. ${ }^{19}$

Dua tahun pertama setelah lahir merupakan periode kritis otak anak-anak berkembang-ment. Dalam tahap itu, tidak terpenuhinya gizi pada anak-anak dapat menyebabkan memperpendek dendrit apikal di otak yang menyebabkan penurunan fungsi otak dan mempengaruhi keterampilan gerak, perhatian, memori, dan kemampuan kognitif (Onis et al, 2016). Oleh karena itu, masalah gizi buruk itu terkait erat dengan kecerdasan menurun dari anak-anak, dan itu menyebabkan kognitif rendah.

\section{KESIMPULAN DAN SARAN}

\section{Simpulan}

Hasil uji statistik dapat disimpulkan bahwa ada perbedaan bermakna antara konsumsi suplemen zinc $20 \mathrm{mg} 2 \mathrm{x}$ seminnggu selama 3 bulan dengan tidak konsumsi zinc terhadap peningkatan tinggi badan (Dengan uji MannWhitney, diperoleh angka signifikansi 0,000).

\section{Saran}

Pemberian zinc kepada balita stunting terutama usia kurang dari 2 tahun secara rutin $2 \mathrm{x}$ seminggu sebanyak $20 \mathrm{mg}(10 \mathrm{ml})$ diimbangi dengan pemantauan berkala oleh petugas kesehatan setempat dengan tetap mengkonsumsi makanan sebagai sumber nutrisi alami bagi balita stunting.

\section{DAFTAR PUSTAKA}

1. Caballero B, Maqbool A. International Nutrition. In : Walker WA, Watkins JB, Duggan C. Nutrition in Pediatrics. Third Edition. London : BC Decker Inc; 2003. p 195-198.

2. Kementerian Kesehatan RI Direktorat Jenderal Bina Gizi dan Kesehatan Ibu dan Anak. Keputusan Menteri Kesehatan Republik Indonesia Nomor : 1995/MENKES/SK/XII/2010 Tentang
Standar Antropometri Penilaian Status Gizi Anak. Jakarta; 2011

3. Badan Penelitian dan Pengembangan Kesehatan Departemen Kesehatan RI. Laporan Hasil Riset Kesehatan Dasar 2010. Jakarta; 2010. p iii, 23, 26

4. Puspitasari FD, Sudargo T, Gamayanti IL. Hubungan Antara Status Gizi dan Faktor Sosiodemografi dengan Kemampuan Kognitif Anak Sekolah Dasar di Daerah Endemis GAKI. Gizi Indonesia 2011; 34(1):52-60

5. Astari LD, Nasoetion A, Dwiriani CM. Hubungan Konsumsi ASI Dan MP- ASI Serta Kejadian Stunting Anak Usia 6-12 Bulan di Kabupaten Bogor. Media Gizi dan Keluarga Juli 2006; 30 (1) 15-23

6. Roosita K, Sunarti E, Herawati T. Nutrient Intake and Stunting Prevalence among Tea Plantation Workers' Children in Indonesia. Journal of Developments in Sustainable Agriculture 2010; 5: 131-135. [accessed Desember 10, 2012]. Available from: URL http:/www.jstage.jst.go.jp/article/jdsa/5/1/5 _1_131/_pdf.

7. Susilowati, Kusharisupeni, Fikawati S, Achmad K. Breast-feeding duration and children's nutritional status at age 12-24 months. Paediatrica Indonesiana January 2010; 50: 56-61

8. Imdad A, Yakoob MY, Bhutta ZA. Impact of maternal education about complementary feeding and provision of complementary foods on child growth in developing countries. BMC Public Health 2011; 11(Suppl 3):S25. [accessed December 10, 2012]. Available from: URL: http://www.biomedcentral.com/14712458/11/S3/S25.

9. Rah JH, Akhter N, Semba RD, de Pee S, Bloem MW, Campbell AA, et al. Low dietary diversity is a predictor of child stunting in rural Bangladesh. European Journal of Clinical Nutrition 2010; 64: 
1393-1398. [accessed December 13, 2012]. Available from: URL: www.nature.com/ejcn.

10. Astari LD, Nasoetion A, Dwiriani CM. Hubungan Karakteristik Keluarga, Pola Pengasuhan dan Kejadian Stunting Anak Usia 6-12 Bulan. Media Gizi dan Keluarga 2005; 29 (2): 40-46

11. Jesmin A, Yamamoto SS, Malik AA, Haque MA. Prevalence and Determinants of Chronic Malnutrition among Preschool Children: A Cross- sectional Study in Dhaka City, Bangladesh. J Health Popul Nutr October 2011; 29(5):494-499. [accessed December 10, 2012]. Available from:

URL:

http://www.ncbi.nlm.nih.gov/pmc/articles/

PMC3225111/

12. PERSAGI. Penuntun Konseling Gizi. Jakarta : PT. Abadi; 2011. Hlm 12,25- 47

13. Noviati, Susanto JC, Selina H, Mexitalia M. The influence of intensive nutritional counseling in Posyandu towards the growth 4-18 month old children. Paediatrica Indonesiana 2006; 46: 57-63

14. Ramli, Agho KE, Inder KJ, Bowe SJ, Jacobs J, Dibley MJ. Prevalence and risk factors for stunting and severe stunting among under-fives in North Maluku province of Indonesia. BMC Pediatrics
2009; 9:64. [accessed December 10, 2012]. Available from:

URL: http://www.biomedcentral.com/14712431/9/64.

15. World Health Organization (WHO). Infant and Young Child Feeding. WHO; 2009. p 4.

16. Badan Pusat Statistik. Istilah Statistik. Jakarta; 2013. [accessed Novenber 10, 2013]. Available from: URL: http://www.bps.go.id/menutab.php?tab $=6 \&$ ist $=1 \&$ var $=\mathrm{P}$

17. Azwar S. Sikap Manusia Teori dan Pengukurannya. Edisi kedua. Yogyakarta: Pustaka Pelajar; 2011. Hlm 154-157

18. Supariasa IDN, Bachyar B, Ibnu F. Penilaian Status Gizi. Jakarta: EGC; 2002. hlm 114

19. Candra, Aryu. Pengaruh Suplementasi Zinc dan Zat Besi Terhadap Berat Badan dan Tinggi Badan Balita. JNH (Journal of Nutrition and Health). 5(1); 2017; 37-44. Available from URL: ile:///F:/STIKES\%20BUP/Tugas/Smstr\%20 3/E\%20journal/E\%20Journal\%20Zinc/PDF /Dalam\%20negeri/13747-51491-2-PB.pdf 